\title{
Germany and the EU-Eastern Enlargement
}

\section{Wichard WOYKE}

\section{History of Enlargement - overview}

The EU was founded as the ECSC in 1951 by the following six European countries: Belgium, the Netherlands, Luxemburg, France, Italy and Germany. 1957 followed the European Economic Community (EEC) and the European Atomic Energy Community (EURATOM), founded by the same countries. In 1967 the institutions of the three communities were combined. The development of these continental communities was very successful. That is the reason why other European countries became members of the European communities.

Five successive enlargements have followed since then:

- In 1973, Denmark, Ireland and the United Kingdom joined the European Community.

- In 1981, Greece became a Member State.

- In 1986, Spain and Portugal became members.

- In 1995, Austria, Finland and Sweden joined the EU.

- In 2004, the Czech Republic, Estonia, Cyprus, Latvia, Lithuania, Hungary, Malta, Poland, Slovakia and Slovenia joined. It was a historic enlargement which signified the re-unification of Europe after decades of division.

- On 1 January 2007 Romania and Bulgaria also joined, completing this historic process.

\section{The collapse of Communism}

In 1989/90 the communist/socialist world collapsed. This development was a tremendous challenge for the EC. Before the wall came down the EC had mainly dealt with the policies in Western Europe and was now preoccupied with postcommunist Eastern Europe. Meanwhile, the EU aimed to ensure political stability in Central and Eastern Europe to protect itself from the negative spillover consequences of instability. Furthermore, the EU had to fulfil the promises made in earlier times that, should geopolitical circumstances allow a membership of the EU. The question was no longer if the CEECs could become members of the EU but when these countries could enter the community. Within the EU countries began a process of reflection. Countries like France were at first hesitating when President Mitterrand proposed on the eve of the year 1990 a new "European Confederation", a loose grouping of states, with the CSCE members but without the big powers US and Soviet Union (c. Woyke 2010, p. 134 ff). 
President Mitterrand preferred to deepen the Community before taking on board new members, because the ratification of a deepened treaty made it harder for the CEECs to become member of the EU. But he did not get any support for his idea, either in the EU or in the CEECs. On the contrary most of the politicians in West- and Eastern Europe rejected his plan. The CEECs strived for membership in the EU. Also in Germany the idea of a European Confederation was rejected. So at last in 1993 the definitive decision was made that the place of these countries should be in the EU.

On the European Council in June 1993 in Helsinki the EU leaders decided that those countries could enter the community when they fulfilled the criteria. According to Article 49 of the Treaty on European Union, any European country which respects the principles of the European Union can in theory become a member of the Union:

In preparation for the fifth round of enlargement - the largest in the history of the EU (eastward enlargement) - the European Council formulated accession criteria in Copenhagen in 1993. The "Copenhagen Criteria", which were defined more precisely through the subsequent enlargement process, provide important orientation for candidate countries.

According to these criteria, accession candidates must fulfil the following requirements to become members of the EU:

- stable institutions to guarantee democracy, the rule of law, human rights and respect for and protection of minorities (political criterion);

- a functioning market economy and the capacity to cope with competitive pressure and market forces within the EU's internal market (economic criterion);

- the ability to take on all the obligations of membership, i.e. the entire body of EU law and policy known as the acquis communautaire, and adherence to the aims of political, economic and monetary union (acquis criterion).

The European Council in Copenhagen further emphasized that the Union's capacity to absorb new members, while maintaining the momentum of European integration, is also an important consideration of both the Union and the candidate countries. The EU's absorption capacity was long regarded as the "forgotten criterion" of Copenhagen. This condition, over which candidate countries themselves have little influence, grows in significance with each new round of enlargement.

\section{Germany and the Eastern enlargement}

With the coming down of the Wall the German question was back. The questions now became: What is going on with Germany? Will Germany stay in the European integration process? Would Germany drift away from the integration process and form a pan-European community centered on the eastern part of Europe? Or would there be a German-Russian dominion? In the 2+4 treaty from September 1990, a substitute for a German Peace Treaty, Germany was given its independence 
and the right to chooses alliances. But the United Germany continued mainly the foreign policy of the old FRG of Bonn and stayed in NATO and the European organisations. In the preamble of the German basics law, we can read: "Conscious of its responsibility before God and mankind, filled with the resolve to preserve its national and political unity and to serve world peace as an equal partner in a united Europe ...". Article 23 stresses the European dimension of the united Germany:

"(1) With a view to establishing a united Europe, the Federal Republic of Germany shall participate in the development of the European Union that is committed to democratic, social, and federal principles, to the rule of law, and to the principle of subsidiarity, and that guarantees a level of protection of basic rights essentially comparable to that afforded by this Basic Law. To this end the Federation may transfer sovereign powers by a law with the consent of the Bundesrat. The establishment of the European Union, as well as changes in its treaty foundations and comparable regulations that amend or supplement this Basic Law, or make such amendments or supplements possible, shall be subject to paragraphs (2) and (3) of Article 79.

(2) The Bundestag and, through the Bundesrat, the Länder shall participate in matters concerning the European Union. The Federal Government shall keep the Bundestag and the Bundesrat informed, comprehensively and at the earliest possible time.

(3) Before participating in legislative acts of the European Union, the Federal Government shall provide the Bundestag with an opportunity to state its position. The Federal Government shall take the position of the Bundestag into account during the negotiations. Details shall be regulated by a law. Furthermore the basic law makes it possible by Article 24 to transfer sovereign powers: "(1) The Federation may by a law transfer sovereign powers to international organizations.

(1a) Insofar as the Länder are competent to exercise state powers and to perform state functions, they may, with the consent of the Federal Government, transfer sovereign powers to transfrontier institutions in neighbouring regions.

(2) With a view to maintaining peace, the Federation may enter into a system of mutual collective security; in doing so it shall consent to such limitations upon its sovereign powers as will bring about and secure a lasting peace in Europe and among the nations of the world.

(3) For the settlement of disputes between states, the Federation shall accede to agreements providing for general, comprehensive, and compulsory international arbitration. ${ }^{1}$

In the united Germany, at the center of Europe after the end of the east-westconflict, was not only a hidden, but also a very open consensus between all the parties of the Bundestag, that the way of a united Germany is the membership in the European Communities, because Germany was and is one of the biggest

1 Law amending the Basic Law of 21 December 1992. 
beneficiaries of the integration process. And there was a new consensus too, that the CEECs should be integrated into the EC. Because of Germany's geographical position and its security and economic interests in Eastern Europe, it has always been clear that the eastern enlargement would be a "German-led enlargement" (Kolankiewicz 1994, 490). Already before the EU received a consensus about the enlargement strategy towards Eastern Europe, the united Germany had made an Eastern policy of its own. Chancelor Helmut Kohl and Foreign Minister Hans Dietrich Genscher argued already in 1991 in several speeches for the membership of Poland, Hungary and Czechoslovakia. In 1991/1992 there were concluded treaties with the neighbour states Poland, Czechoslovakia and Hungary in which Germany supported their EU-membership. Concerning the date of membership Germany's political leaders were very vague. From the Foreign affairs Office it was stated in 1992 that Poland, Hungary and Czechoslovakia could enter the Union around the year 2000. Germany tried to "Europeanize" the process of Eastern enlargement because Germany alone felt too weak to master the process of democratization in the CEECs. Enlargement would give the EU a greater collective presence in Eastern Europe, and would provide other West European countries with some leverage over German actions in Central and Eastern Europe.

Germany's government turned its attention after the final ratification and enactment of the Maastricht treaty in October 1993 to Eastern Europe. During its EU-presidency in the second semester of 1994, the German government declared the integration of Eastern Europe as a central priority. A major step in this process was the "pre-accession" strategy, approved by the European Council in Essen in December 1994. This strategy included the double promise of financial and infrastructural aid in the entering process into the Community. The pre-accession strategy was designed to prepare the candidate countries for future membership. It encompassed the following frameworks and mechanisms: Europe Agreements/ Association Agreements/Stabilisation and Association Agreements, Accession Partnerships/European Partnerships.

There were at least three major reasons for the German support of the widening process towards Eastern Europe. First, stabilisaty in the eastern area would increase German security too. Second, Germany could benefit economically from the membership of the CEECs in the EU. Third, moral reasons from history led to the support. Furthermore, membership was seen as an equivalent for the support of some CEECs in the unification process.

\subsection{Political and Military security}

Traditionally, Germany's security was a major concern. Throughout its history Germany has always paid the price in terms of war and insecurity of its central geographical position. Often, Germany or parts of it were objects of big powers 
surrounding the German Länder. During the cold war, West-Germany and EastGermany were as members of NATO and the Warsaw Pact respectively, located at the front. Two political and military systems bounced against each other. The situation from 1945-1989/90 was partly extremely unsecure. Nevertheless the two big military coalitions guaranteed a certain security in Europe. After the Wall came down and Germany was reunited, this country again became once again a geopolitical uncertainty to its east.

"From the standpoint of German security interests, EU enlargement would offer two primary benefits. First, it would move Germany from the eastern border of the EU to a more comfortable position to its middle. Thus it would have, in the form of Poland, the Czech Republic, Hungary, and possibly other postcommunist states the 'buffer zone' of allied and friendly countries that it has so often sought in the past, although through more unpleasant means" (Baun 1997, 5f.). Behind the ideas of the 'buffer zone' was the uncertain development of the Soviet Union/Russia, whose nationalism should concern the eastern European area.

The second big security benefit for Germany would be the political stability it would bring to Eastern Europe. Through enlargement - and already in the prospect of it -, the EU could export political stability which helped to guarantee its own security. A development which brought freedom and economic welfare in one part of Europe could not be maintained if there are open frontiers. The idea that the political system of liberal democracy would be widened up to the Polish/ Russian border increased the number of democracies in Europe and in the same way increased security as democracies do not tend to fight war against each other.

The third advantage lies in terms of internal security. Enlargement expands the area that enjoys liberty, security and the rule of law to embrace new member states. This enables them to strengthen the fight against organized and international crime. More effective measures can be taken to combat drug trafficking and trafficking of people as well as terrorism. Money laundering and financial crime too can be tackled more effectively. Asylum and refugee policies were standardized. Alongside equal reception conditions, common standards apply to asylum procedures and refugee status. With the support of EU states, shortcomings in the field of justice and domestic affairs in accession states can be remedied and suitable authorities and institutions put in place.

Enlargement is therefore a key transformational force, inspiring democratic change and economic liberalisation among those who wish to join. It is at the heart of the EU's soft power to extend the zone of peace, stability and prosperity on the continent. The appeal of the EU has been instrumental in the peaceful democratic transformation of Central and Eastern Europe and it remains the driving force for the reforms in the Western Balkans and in Turkey. It is in the EUs - and of course Germany's - vital interest to export stability into their neighbourhood rather than import instability from there. 


\subsection{German economic interests and the EU-enlargement}

"Just as Germany's geographical location makes it the most vulnerable member state to security threats from the east, it also makes Germany the country most likely to benefit from the economic opportunities afforded by postcommunist Europe" (Baun 1994. 6-7). First of all in Germany politicians thought to get a push in foreign commerce. And indeed trade between the applicant countries and later the new member countries doubled in a short time. The gross domestic product of Germany (and Austria) alone has risen by about $0.5 \%$ per annum thanks to enlargement. Rising exports to the accession states ensures higher economic growth in the EU member states and secures jobs there. Second, German companies can transfer their seats to Eastern and Central Europe, where the salaries and wages are much inferior to the salaries in Germany. Incidental wages are lower and, thus, companies are able to produce more cheaply. So they have a better situation on the world market. Since 1989 numerous German companies in sectors such as automobiles, chemicals and small manufacturing have established factories in the CEECs from which they supplied the EU and other markets. Private businesses from the old EU states can found branches in the new member states more easily and underpin their international competitiveness. Existing jobs are saved and new ones created. Enlargement makes possible extensive economic links with neighboring states in Eastern Europe. The former East Germany, in particular, can be expected to attract businesses engaged in trade with Eastern Europe. All in all, the EU's trade with the states of Central and Eastern Europe has quadrupled since 1989. Germany benefits particularly from this development. Today German companies sell more in the accession states than in the USA and Canada together.

Furthermore the CEECs have benefited tremendously from integrating their economies with the bigger and wealthier ones in Western Europe since the early 1990s. The objective of joining the EU served as an external anchor for reforms. As a result, these countries have gone from post-Communist chaos to orderly EU membership in less than fifteen years. And although the pace of reforms has slowed recently, the growth prospects in the region remain good. For the 'old' memberstates, the economic impact of enlargement has also been positive - although it has been much smaller, simply because the economies of the new members are so small. Some EU countries, in particular Austria and Germany, have done particularly well out of exporting to Central and Eastern Europe's fast-growing markets. And many West European companies have profited substantially from investing in retail, telecoms, energy or the media in the new Europe. But enlargement is changing the EU economy in a more profound way. Enlargement has allowed the emergence of a new, pan-European division of labour. This, in turn, will help the EU economy to stay competitive in a globalised world economy. 


\subsection{Moral interests}

Last but not least, Germany's interests in eastern enlargement derived from the attitude of the country in history. Not only the time of the Second World War burdened the German position towards the Eastern neighbours but also the time from the medieval age to the $20^{\text {th }}$ century shows many conflicts between German provinces and their eastern neighbours. The German feelings of moral duty and responsibility stem from the desire to atone for Germany's past aggression towards Eastern Europe. In the 90, leading politicians in West Germany realized more and more that the economic prosperity was also built on Soviet victimization of East Europeans and the erection of the iron curtain. The modernization process in the western part of Germany could be developed without being overstrained by claims from the east (cf. Pond 1966, pp. 32-33). But it was not only the historical dimension as one of the reasons for the promoton of the EU-enlargement. Furthermore, there was a debt of gratitude owed to the people of Eastern Europe, especially Hungarians, Poles and Czechs, who enabled the possibility of German unity in freedom and peace. In May 1989, it was Hungary opening the iron curtain for the first time at a pan European festival in Sopron. And in September the foreign minister Gyula Horn from Hungary cut with his Austrian homologue the iron curtain. In the German embassy in Prague, up to 5000 refugees from the GDR were supported by the Czech offices. There were deep feelings about the "gift of unification", which enabled the former GDR to automatically enter in NATO and the EU, while the other countries from the Warsaw Pact had to wait outside.

\section{The entrance of 12 countries 2004/2007}

On May $1^{\text {st }}$ in 2004 Poland, Hungary, Czech Republic, Estonia, Latvia, Lithuania, Slovakia, Slovenia, Malta and Cyprus became members of the EU. In 2007 followed Romania and Bulgaria as latecomers. It was the biggest enlargement ever, for the EU was nearly doubling its membership, increased its territory by 25 $\%$, its population by $20 \%$ and its GNP by ca. $5 \%$. But the membership of the new countries was not appreciated by all inhabitants in the old EU countries. This could be seen in a speech of former chancellor Schröder in the German Parliament on the occasion of the entray of these states. Schröder addressed the fears many Germans have about enlargement, saying he understood many people were worried about losing their jobs to lower wage competition in the new countries". The federal government takes seriously the concern that enlargement has increased pressure on the labor market", he said, justifying the employment restrictions Germany has implemented for new EU citizens. He also admitted globalization might cause some German companies to move jobs abroad, but added that such shifts could help strengthen their core business at home. "That can also lead to more 
employment in our own country... Together we have to make it clear that the opportunities outweigh the risks". Schröder indicated that Germany stood to gain much from enlargement by being once again at the heart of Europe. He pointed out that economic integration between old and new members was already underway and that Germany exported nearly as much to its eastern neighbors as it did to the United States. "The enlargement will not make us poorer, but rather richer", he said. However, he also renewed calls for harmonizing EU taxes, saying there could be no one-sided tax competition at the expense of those countries that are net contributors to the EU budget.

\section{EU-Enlargement today}

As the number of EU member states increases, the challenge of balancing enlargement with the capacity for and momentum of integration also grows. In recent years, the parameters of the EU enlargement policy have developed steadily. Within the framework of what is known as the "renewed consensus on enlargement", the EU has since 2006 focused on an enlargement strategy based on the following four principles.

- Consolidation: The EU meets its commitments and keeps the pledges it has made to accession candidates.

- Conditionality: Candidate countries must uphold the fair but rigorous criteria and conditions for accession.

- Communication: Greater transparency and improved communication are to ensure broad-based societal support for the enlargement process.

- Ensuring the EU is capable of absorbing new members: The EU must have the capacity to absorb and successfully integrate new member states without compromising its own ability to take action or its further development.

"The German Government is committed to these principles and is working to continue the enlargement process. At European level, it advocates a measured and judicious enlargement policy. Germany insists that the accession criteria be upheld in order to link enlargement with the process of internal EU consolidation. The German Government considers the EU's absorption capacity and the candidate countries' suitability for accession to be equally essential in decision-making" (auswaertiges-amt 2013).

At present, membership negotiations are underway with three countries: Croatia and Turkey opened negotiations with the EU in 2005, while talks with Iceland began in 2010. The Former Yugoslav Republic of Macedonia (FYROM) has been granted candidate status but has yet to begin formal membership negotiations. There are five further 'potential candidates' which have been recognised by the EU in the Western Balkans region of southeast Europe, meaning that they will be granted candidate status as soon as they fulfil the necessary requirements. These are: Albania, Bosnia and Herzegovina, Montenegro, Serbia and Kosovo. 
Treaty-based relations between the European Union and Turkeybegan already in 1963, when the Ankara Agreement, as it became known, was signed. By this signature Turkey was the second country, after Greece, to sign an Association Agreement with what was then the European Economic Community. The narrow cooperation of the EC with Turkey must be understood as cooperation with a NATO-member during the East-West-Conflict. The Agreement established close economic ties, which in 1995 developed into a customs union. Article 28 for the first time envisaged accession as a possible prospect: "As soon as the operation of this Agreement has advanced far enough to justify envisaging full acceptance by Turkey of the obligations arising out of the Treaty establishing the (European Economic) Community, the Contracting Parties shall examine the possibility of the accession of Turkey to the Community".

Having officially applied for EU membership in 1987, Turkey got candidate status by the European Council in Helsinki in 1999. Once the European Council had concluded in December 2004 that "Turkey sufficiently fulfils the Copenhagen political criteria", ${ }^{2}$ the way was clear to open accession negotiations on 3 October 2005. The negotiation talks between the EU and Turkey are not very easy because France's President Sarkozy (2007-2012) as well as Chancellor Angela Merkel (since 2005) in her role as party leader of the CDU, were against Turkish membership. They preferred a "privileged partnership" with Turkey. Officially, the German Government backed of course the opening of accession negotiations withTurkey and is in favour of conducting them as an open-ended process. But from the government it often emphasized that Turkey's accession to the EU is conditional on the country strictly fulfilling the Copenhagen criteria and implementing the Ankara Protocol in its entirety, as well as on the EU's capacity to absorb new members.

Of a total of 35 chapters under negotiation, only one, Science and Research, has been provisionally concluded to date. Since 2005, another twelve have been opened, the most recent being the chapter on Food Safety, Veterinary and Phytosanitary Policy, which was opened in June 2010. On 21 December 2012, Foreign Minister Westerwelle recommended opening negotiations on additional chapters during the first six months of 2013. For Westerwelle, Turkey had over the past decade made great progress. The country could build bridges to the Islamic world in Europe's neighbourhood. Political developments in the EU's and Turkey's common neighbourhood in the last years have underlined the value of closer liaison. In this context, the European Commission announced in October 2011 a Positive Agenda with respect to Turkey, which was welcomed by the Council of Ministers.

Thanks to its close political, cultural and economic ties with the country- there are nearly 2 mill. Turks living in Germany -, Germany has a special interest in

2 Brussels European Council 16/17 December 2004; Presidency Conclusions, 16238/1/04 REV 1, p. 4. 
Turkey moving closer to EU membership. Germany is also keen for it to keep up the momentum for reform, as this will have a major impact on its EU prospects. Turkey is crucial to stability in Europe's neighbourhood, as well as for the EU's energy supply. It likewise plays an important role in the intercultural dialogue between Europe and its neighbours in the Near and Middle East, as well as North. Nowadays, Germany is in favouring the consolidation of the EU. The last developments in the EU have shown that for most European peoples the enlargement process was too fast. Therefore, they are looking for more consolidation which must be suspected by the European governments.

\section{References}

http://www.auswaertiges-amt.de/EN/Europa/Erweiterung/Grundsätze_Erweiterungspolitik_ node.html (abgerufen am 7.5.2013).

Baun, Michael 1997: Germany and EU Enlargement", (Paper presented at the $5^{\text {th }}$ Biennial ECSA Conference, Seattle, May 29-June 1, 1997.

Kolankiewicz, George 1994: Consensus and Competition in the eastern Enlargement of the European Union, in: International Affairs, 70, pp. 477- 495.

Pond, Elizabeth 1996: Germany finds its Niche as a regional Power, in: The Washington Quarterly, 19, pp. 25-43.

Woyke, Wichard 2010: Die Außenpolitik Frankreichs. Eine Einführung, Wiesbaden. 